\title{
Nurses' Bullying Experiences: A Case study of a Caribbean Major Island Hospital
}

\author{
Elsie Hepburn ${ }^{1}$, Esther Daniel ${ }^{1} \&$ Philip Onuoha ${ }^{1}$ \\ ${ }^{1}$ The UWI School of Nursing, Faculty of Medical Sciences, University of the West Indies, St. Augustine, Trinidad \\ and Tobago \\ Correspondence: Philip Onuoha, The UWI School of Nursing, Faculty of Medical Sciences, University of the \\ West Indies, St. Augustine, Trinidad and Tobago.
}

Received: August 15, 2020 Accepted: September 21, 2020 Online Published: October 13, 2020

doi:10.5539/gjhs.v12n12p17 URL: https://doi.org/10.5539/gjhs.v12n12p17

\begin{abstract}
Purpose: The study was aimed at determining the self-reported experiences of the nurses in the major Island hospital in The Commonwealth of The Bahamas with regard to workplace bullying and their assessment of the support they received following the experience.

Methods: A descriptive quantitative case study was undertaken using all the registered nurses in the Island Hospital. The study utilized a modified pre-validated instrument from the International Labour Office (ILO), International Council of Nurses (ICN), World Health Organization (WHO), and Public Services International (PSI). Analysis was done using the SPSS version 20. The result was presented as frequencies.

Results: Eighty-one (81) respondents completed and returned their copies of the questionnaire giving a response rate of $97.5 \%$. Also, $85.2 \%$ of the respondents reported having moderate bullying experience while $14.8 \%$ reported having maximum bullying experience. As it relates to the self-reported support for bullying, $60.5 \%$ of the respondents indicated that they received little support following a bullying experience. Further, $39.5 \%$ reported that they received some support following a bullying experience. There was no significant relationship between the respondents' demographics and their self-reported experience of bullying or support following a bullying experience $(\mathrm{p} \leq 0.05)$.
\end{abstract}

Recommendation/Discussion: Among others, we recommended that a more deliberate policy instrument be developed for dealing with cases of bullying and to monitor the use of this instrument, noting that the mental health of the nurses are also at risk.

Conclusion: The study revealed that bullying was reportedly high while measures to support staff were reportedly low, a combination the investigators see as concerning in the Island Hospital.

Keywords: bullying, nurses, caribbean, work environment

\section{Introduction}

Workplace bullying is a "repeated health-harming mistreatment of one or more persons by one or more perpetrators (workplacebullying.org, 2018) characterized as a systemic a "non-physical, non-homicidal form of violence that is abusive, and emotionally harms the recipient". ${ }^{1(\mathrm{pl}-2)}$ Bullying, be it overt or covert, is often enacted by persons in position of power or advantage (Workplacebullying.org, 2018; Power, 1999). Every employee wishes to work in a civil environment that is free of real or perceived bullying, or what referred to as lateral violence, aggression or mobbing (Leos-Sheridan, 2008). However, the aforementioned can exist anytime people work together, regardless of gender, race, and organizational structure (Leos-Sheridan, 2008). Anjum, Yasmeen and Yasmeen (2011) documents workplace bullying as a "widespread phenomenon". Further, there appears to be consensus that this unethical behavior is prevalent, indeed a serious workplace issue and permeates all strata within healthcare systems and integrates itself as a cultural norm (Aleassa \& Megdadi, 2014; Ariza-Montes, Muniz, Montero-Simo, \& Araque-Padilla 2013; Essen, Esquival, \& Jha, 2015; McGee, 2014). Nevertheless, Gaffney et al. (2012) noted that silence as it relates to bullying continues to exist in many institutions and it is this silence that perpetuates "underreporting and insufficient and unproven interventions".

A review of internal hospital Incident Forms of a Risk Management Department in a major hospital in the Commonwealth of The Bahamas revealed that nurses employed at this institution feel that bullying exists and has 
become a part of the culture of the institution. This appears to be in line with what literature suggests that up to $25 \%$ of nurses' experience bullying (Quine, 2001; Wilson, 2016). However, although the Incident Forms are reviewed by the Risk Manager daily in this public hospital, a formal study to explore these perceptions or feelings, their validity and strategies used by this public healthcare institution to address bullying was never performed. In fact, despite its existence, there are no documented research findings as it relates to the bullying of nurses in healthcare institutions in the entire Commonwealth of The Bahamas. This study, therefore, is the first as it kind as it relates to the bullying experiences as well as the supports that are availed to the nurses in this respect in this major Island hospital. We envisage that the report from this study will be of assistance to the policy makers regarding incidence, management, and control of such experiences as this is related to job satisfaction and the emotional health of all and sundry (Jackson \& Ashley, 2005).

The theoretical framework used to guide this research was Madeline Leininger's Culture Care Diversity and Universality Theory which was developed in 1991. While her theory is often applied to the clinical management of patients taking their cultural context into consideration, this theory can also help us to understand organizational culture and the role same can play in developing and accepting certain patterns of behaviors such as bullying; be they good and/or bad (Johnston, Phanhtharath, \& Jackson, 2009). However, the theory also explores avenues for restructuring cultural behavioral norms to provide supportive mechanisms for change as needed.

Although definitions of bullying vary, as the authors looked at various manifestations or structures of it, they tend to include terms such as harassment, overt and covert intimidations, repeated show of power, power imbalance which in the end harm employees on the receiving end in more ways than one (Leos-Sheridan, 2008; Chapovalov \&Van Halle, 2015; Durmus, Popcu, \& Yildirim, 2018). It should also be noted that many authors have indicated the prevalence of this phenomenon range from $20 \%$ to as much as $76 \%$ in many jurisdictions including Poland, Korea, Canada, USA, and Barbados (Abed, Morris, \& Sobers-Gannum, 2016; Jackson \& Ashley 2005; Kang \& Lee, 2016; Simnon \& Mawn, 2010; Bajuma, Zdanowski, \& Mendyka, 2012; Berry et al., 2012; Purpora, Cooper, \& Sharifi 2015).

Additionally, a number of studies have identified the factors likely to be in place for this phenomenon to exist and for it to perpetuate. These factors are the independent variables of this study. They are (a) environment and social structure, (b) organizational structure, (c) institutional management structure, and (d) the nurses' demography (Abed, Morris, \& Sobers-Gannum, 2016; Kang \& Lee, 2016; Simnon \& Mawn, 2010; Berry et al., 2012; Bartholomew, 2019; Purpora, Cooper, \& Sharifi, 2015; Chaziioannidis, Bascialla, Chatzivalsam, Vouzas, \& Mitsakos, 2018). In this study, we aim to find out if there is bullying among the nurses in the Hospital and if their demography namely, Age, Gender, Nationality, Years of Employment is related to their experiences.

Similarly, support for those who experience bullying has been identified as a factor that not only assists the employee, it also helps to stop the phenomenon. We hope to ascertain the institutional practices that may be of assistance to the employees who may be experiencing bullying. Various studies indicate that clear policies, collaborative work environment, level of organizational tolerance, and development of specific strategies for helping staff subjected to such experiences go a long to ameliorate the experiences (Gaffney et al., 2012; Meires, 2018; Kang \& Lee, 2016; Berry et al. 2012; Agarwal, 2018; Hansen et al. 2006; Norton et al. 2017; Khubuchandani \& Price, 2015; Nelson et al., 2014; Johnson, Boutain, Tsai, \& de Catro, 2019).

\subsection{Aim}

To ascertain if there are experiences of bullying among nurses in the major Island Hospital and to determine if there are support services available to the nurses.

\subsection{Objectives}

This study is hinged on the following objectives:

1) To describe the nurses' self-reported experiences of bullying at this Major Island public hospital.

2) To describe the support the nurses at this hospital receive following their experiences of bullying.

3) To determine if nurses' self-reported (a) experiences and (b) support received; are associated with their socio-demographic characteristics.

\section{Methodology}

\subsection{Design}

It is a descriptive case study of this Caribbean Island public hospital related to nurses' experiences of bullying. We chose to investigate this phenomenon in this major hospital hoping that it will give an indication of what may be 
likely in the other smaller health care institutions in the Island Country (Houser, 2018).

\subsection{Population and Sampling}

All of the nurses in the hospital were engaged provided they gave and signed the informed consent and were not in a managerial position. We surmised that those in the managerial positions are not likely to be bullied by the nurses in the lower positions as the investigation is limited to bullying among nurses and to nurses. In all there were 83 nurses and so no sampling was necessary (Zhao, Tian, Cai, Claggett, \& Wei, 2013). Only 81 consented. Table 1 shows the distribution of the nurses.

Table 1. The proportional allocation of nurses based upon their area of deployment

\begin{tabular}{lc}
\hline Area of Deployment & Number of Nurses Working in the Area of Deployment \\
\hline Emergency Room & 21 \\
\hline Psychiatric Unit & 6 \\
\hline Pediatrics Ward & 5 \\
\hline Medical Ward & 7 \\
\hline Surgical Ward & 7 \\
\hline Intensive Care Unit & 10 \\
\hline Operating Theater & 8 \\
\hline Maternity Ward & 7 \\
\hline Special Care Baby Unit & 7 \\
\hline Continuing Nursing Education & 1 \\
\hline Admissions \& Discharge & 1 \\
\hline Nursing Relief Pool & 3 \\
\hline Total & $\mathbf{8 3}$ \\
\hline
\end{tabular}

\subsection{Ethical Consideration}

We sought for and secured the ethical approval from the University of the West Indies, as well as the Research \& Ethics Committee, Public Hospitals Authority (PHA) and Ministry of Health, Bahamas. Permission was gained from the hospital as well as from the participants who signed their respective informed consent.

\subsection{Instrument}

We adapted the self-administered standardized, validated questionnaire, a Workplace Violence in the Health Sector Country Case Study Research Instruments Survey Questionnaire English (ILO/ICN/WHO/PSI, 2003) instrument that was jointly developed in Geneva Switzerland by the International Labor Office (ILO), the World Health Organization (WHO), the International Council of Nurses (ICN) and the Public Services International (PSI). The document has been effectively and widely employed in several research studies and has also been instrumental in the development of strategies and policies to mitigate violence in the workplace in institutions globally (ILO/ICN/WHO/PSI, 2003). The adaptation included the use of the questions from bullying/mobbing aspect of the tool while we modified slightly the demography to include nationalities that were reflected in the nursing population of this major hospital. The questionnaire consists of two sections with the first section requesting data related to personal demographics and workplace characteristics as it relates to the perpetrators of bullying. There are a total of 10 items in this section. The second part of the adjusted questionnaire is related to workplace bullying/mobbing in terms of the participant's personal experience with bullying, its prevalence and measures taken by the institution to deal with same. This section has 12 items. The adjusted instrument was pretested and with a Cronbach's of . 709 we deemed the instrument good enough for the full study.

\subsection{Statistical Analysis Plan}

The data collected was coded, analyzed, and tested using the Statistical Package for the Social Sciences (SPSS) version 20. The chi-squared test was used to determine the association between the respondents' experiences of bullying and their demographic characteristics. $\mathrm{P} \leq 0.05$ is used to denote statistical significance. 


\subsection{Scoring of Self-Reported Experiences of Bullying}

The data was assembled in three categories namely, demographics, nurses' experiences with bullying and the support nurses' received post a bullying experience. The mean scores for nurses' experiences with bullying and the support nurses' received post a bullying experience were calculated and used to determine the nurses self-reported experiences and self-reported support levels related to bullying respectively. Based on the mean score which is expected to range between 0 and 14, the self-reported experiences of bullying were categorized in Table 2 .

Table 2. Scoring and categorization of Bullying Experiences

\begin{tabular}{ll}
\hline Score & Categorization \\
\hline $0-4$ & Little to No Experience \\
$5-9$ & Moderate Experience \\
$10-14$ & Maximum Experience \\
\hline
\end{tabular}

\section{Self-Reported Support after a Bullying Experiencing Performance Scores}

Similarly, based on the mean score, the self-reported support after a bullying experience was as categorized in Table 3. It is expected to range between 0 and 34 .

Table 3. Scoring and categorization of Support received following experiences of Bullying

\begin{tabular}{ll}
\hline Score & Categorization \\
\hline $0-6$ & No Support \\
$7-13$ & Little Support \\
$14-20$ & Some Support \\
$21-27$ & Sufficient Support \\
$28-34$ & Maximum Support \\
\hline
\end{tabular}

Findings were interpreted and presented as frequencies. The study findings were presented in summative form and no individual person's information was singled out.

\section{Results}

\subsection{Demographic Characteristics}

Table 4 summarizes the demography of the respondents. Eighty-one (81) sampled respondents completed and returned their questionnaires giving a response rate of $97.5 \%$. Two respondents did not participate in the study as one was on maternity leave and the other was on industrial leave related to a work-related incident. All responses were included in the final analysis. The mean age of the respondents was 41.7 years with standard deviation of \pm 1.745 and $33.3 \%$ were between the age group of $30-34$ years. A little over ninety percent $(90.1 \%)$ of the respondents were females and the remainder were males $(9.9 \%)$. The largest groups of respondents were Bahamians at $77.8 \%$, followed by Filipinos at $21 \%$ and one African respondent accounting for $1.2 \%$. Forty-two percent $(42 \%)$ of the study respondents had between $1-5$ years of working experience and a little over thirty-two percent $(32.1 \%)$ had between $6-10$ years of working experience. 
Table 4. Demographic Characteristics of Respondents at A Major Hospital in The Bahamas $N=81$

\begin{tabular}{|c|c|c|}
\hline Characteristics & Frequency & Percentage (\%) \\
\hline \multicolumn{3}{|l|}{ Age Range } \\
\hline $0-24$ & 4 & 4.9 \\
\hline $25-29$ & 19 & 23.5 \\
\hline $30-34$ & 27 & 33.3 \\
\hline $35-39$ & 9 & 11.1 \\
\hline $40-44$ & 11 & 13.6 \\
\hline $45-49$ & 6 & 7.4 \\
\hline $50-54$ & 2 & 2.5 \\
\hline $55-59$ & 1 & 1.2 \\
\hline $60+$ & 2 & 2.5 \\
\hline \multicolumn{3}{|l|}{ Gender } \\
\hline Female & 73 & 90.1 \\
\hline Male & 8 & 9.9 \\
\hline \multicolumn{3}{|l|}{ Nationality } \\
\hline Bahamian & 63 & 77.8 \\
\hline African & 1 & 1.2 \\
\hline Filipino & 17 & 21.0 \\
\hline \multicolumn{3}{|c|}{ Length of Employment } \\
\hline $1-5$ years & 34 & 42.0 \\
\hline $6-10$ years & 26 & 32.1 \\
\hline $11-15$ years & 13 & 16.0 \\
\hline $16-20$ years & 3 & 3.7 \\
\hline $21-25$ years & 4 & 4.9 \\
\hline
\end{tabular}

\subsection{Nurses' Self-Reported Experiences}

Figure 1 illustrates the experiences of the nurses in this Island hospital regarding bullying. It shows that $85.2 \%$ of them reported experiencing bulling at moderate level while $14.8 \%$ indicated that they experienced bullying at the maximum level. Also figure 2 shows the nurses description of the level of support they received following bullying. The figure illustrates that while $39.5 \%$ of the nurses indicate that they received "some support", $60.5 \%$ indicate that they did not received "little support". Regarding whether there are relationship between the dependent variables of study (experiences of bullying and support for bullying experience) and the independent variables (the nurses' demography), Tables 5 and 6 show that there are no associations between (a) the nurses' experiences of bullying, (b) support nurses' received following bulling; and their demographic characteristics, namely age, gender, nationality, years of employment $(\mathrm{p}<0.05)$. 


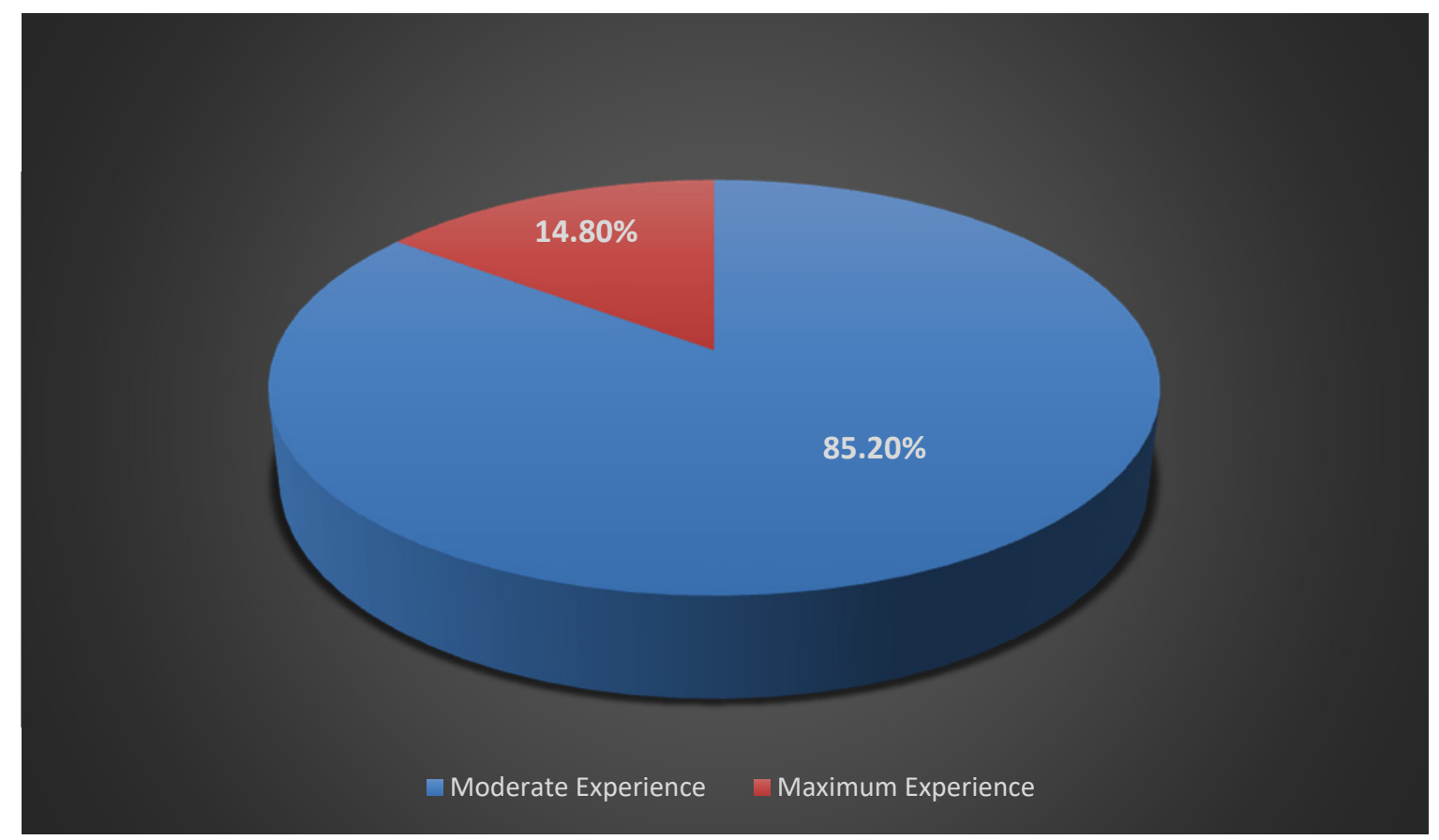

Figure 1. Nureses' self-reported edperiences of bullying. $\mathrm{N}=81$

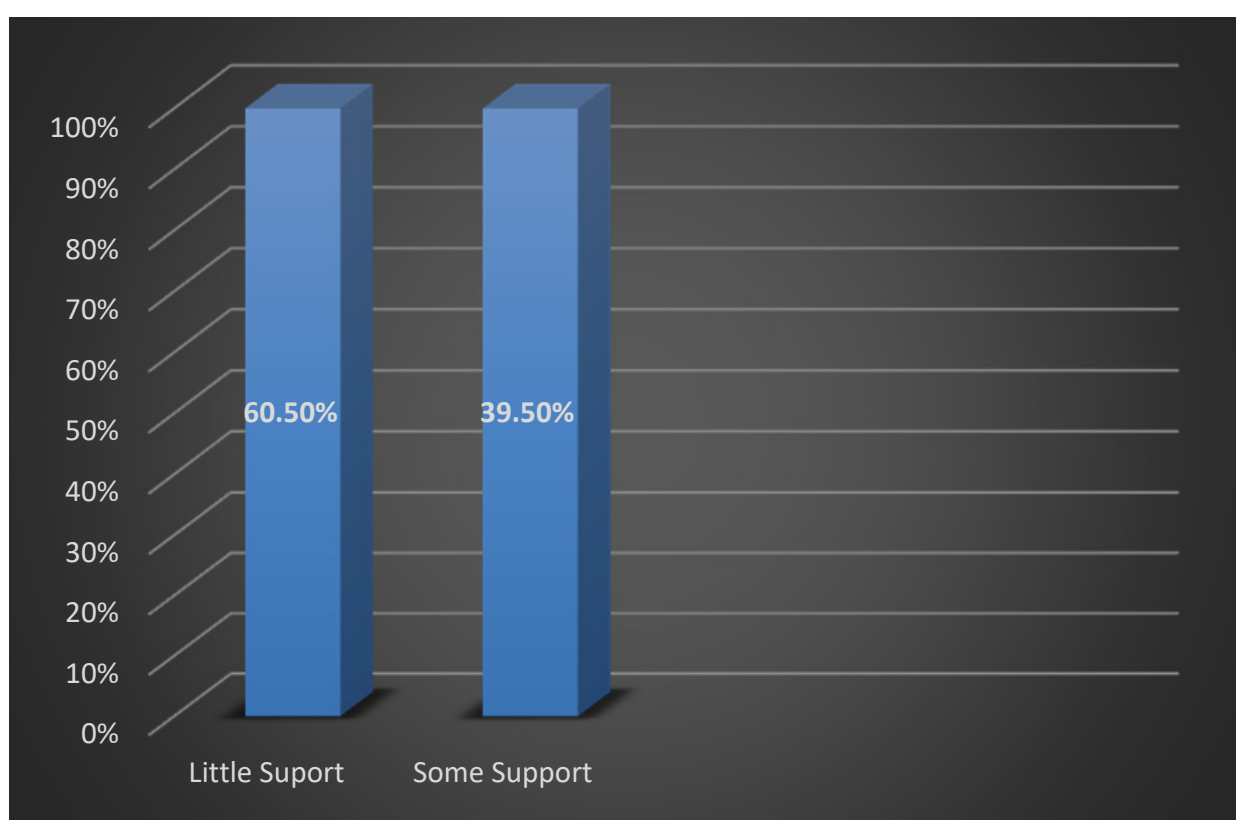

Figure 2. Nurses' Self-Reported Experiences of Support Following Bullying: N=81

Table 5. Relationship between Self-Reported Experiences and the Respondents' Demographics

\begin{tabular}{llll}
\hline & Value & DF & Sig. \\
\hline Age & 7.053 & 8 & 0.531 \\
Gender & .110 & 1 & .740 \\
Nationality & 5.950 & 2 & .133 \\
Length of Employment & 8.540 & 8 & .382 \\
\hline
\end{tabular}


Table 6. Association between Respondents' self-reported Support and their Demographics

\begin{tabular}{llll}
\hline & Value & DF & Sig. \\
\hline Age & 8.549 & 8 & .382 \\
Gender & .103 & 1 & .508 \\
Nationality & 2.780 & 2 & .249 \\
Length of Employment & 3.659 & 4 & .454 \\
\hline
\end{tabular}

\section{Discussion}

The finding that all of the nurses in this case study reported experiences about bullying is concerning. Indeed, that the experiences range from moderate $(85.2 \%)$ to maximum (14.8\%) is troubling. Although this is a case study of one major Island Hospital, it should be noted that nearly all the nurses in the hospital participated in the study. This is concerning given that bullying experiences have been defined variously to include such descriptions as the personal encounter or exposure to bullying of nurses in their work environment where they are subjected to "repeated and over time offensive behavior through vindictive, cruel, or malicious attempts to humiliate or undermine an individual or groups of employees" (ILO/ICN/WHO/PSI, 2003)

It should also be noted that some of the nurses have worked in this hospital for as long as 25 years in this condition. This is dangerously unhealthy and needs to be addressed urgently. This high incidence confirms all studies reviewed in this regard (Ariza-Montes, Munix, Montero-Simo, \& Araque-Padilla, 2013; Tinaz, 2006; Lipscomb, London, McPhaul, Ghaziri, Geiger-Brown, \& Johnson, 2015; Oxenstierna, Elofsson, Gjerde, Hanson, \& Theorell, 2012).

Equally, with the 5 categories of support indicated, ranging from little to maximum levels, it is also a surprise that the nurses in this hospital indicated that majority received little (60.5\%) while $39.5 \%$ received "some support". To juxtapose this level of support with the prevalence of the bullying experience is serious. Again, to imagine that some of the nurses have been in this work environment for 25 years should be revealing. Although many authors reviewed indicate that experiences of bullying among nurses is pervasive among nurses, none has reported these situations to this level (Gaffney et al., 2012, McMahon, McCurtain, O’Sullivan, Murphy, \& Turner, 2019, Hansen, Hogh, Persson, Karlson, Garde, \& Orbaek, 2006; Nelson et al. 2014; Johnson \& Boutain, Tai, \& de Castro, 2015).

Further, that there was no significant difference between the (a) nurses experience of bullying; (b) their support for bullying and their demography is not surprising. It suggests that the nurses irrespective of their age, length of employment, gender, nationality, etc experience bullying same way, and when they do experience bullying, they do not get sufficient support from the organization. These are concerning revelations in this Island Hospital.

\subsection{Study Limitations}

We note that the study is a case study of an Island Hospital and may not accurately reflect what happens elsewhere in the Island. Also, the study did not take into account the fact that the data from this study is self-reported. One cannot ascertain the extent to which the nurses are completely honest. We also note that the data collection coincided with the period the Island was subjected to the Hurricane Dorian, a natural situation we could not tell if it impacted on their nurses' stress level and hence on their disillusionment. However, the investigators used their experience in the field including their training in ethics to ensure the administration of the instrument, data collection, entry and treatment were done in such a way that most of the extenuating circumstance would have been minimized that they do not to impact the truthfulness of the findings.

\section{Conclusion}

This study revealed that nurses working at this major hospital in The Bahamas do experience workplace bullying and that generally the support or management for workplace bullying in this hospital is largely insufficient.

\subsection{Recommendations}

We recommend that a more qualitative study to done to look at the policies, and extent of use of policies available for attending to experiences of bullying in the hospitals be conducted. We also recommend that more precise, and clear policies be developed for dealing with workplace bullying in hospitals and other healthcare institutions in the Island be developed and be seen to be in use.

\section{Acknowledgements}

We are grateful to all the nurses in the Island hospital for their responses and to all the agencies and institutions 
who granted us the permission and approval to undertake the study.

\section{Competing Interests Statement}

The authors declare that there are no competing or potential conflicts of interest.

\section{References}

Abed, M., Morris, E., \& Sobers-Grannum, N. (2016). Workplace violence against medical staff in healthcare facilities in Barbados. Occupational Medicine, 66(7), 580-3. PMid:27371658. https://doi.org/10.1093/occmed/kqw073

Agarwal, D. P. (2018). Here Is Why We Need to Talk About Bullying in The Work Place. Forbes. Forbes Magazine, 2018. Retrieved July, 2019, from https://www.forbes.com/sites/pragyaagarwaleurope/2018/07/29/workplace-bullying-here-is-why-we-need-t o-talk-about-bullying-in-the-work-place/\#2e4ead093259

Aleassa, H. M., \& Megdadi, O. D. (2014). Workplace bullying and unethical behaviors: A mediating model. International Journal of Business and Management, 9(3), 157-169. https://doi.org/10.5539/ijbm.v9n3p157

Anjum, A., Yasmeen, K., \& Yasmeen, K. (2011). Bullying at work: A comprehensive definition and consequences based on an empirical study. International Journal of Human Resource Studies, 1(1), 80-8. https://doi.org/10.5296/ijhrs.v1i1.907

Ariza-Montes, A., Muniz, N., Montero-Simó, M., \& Araque-Padilla, R. (2013). Workplace Bullying among Healthcare Workers. International Journal of Environmental Research and Public Health, 10(8), 3121-39. PMid:23887621 PMCid:PMC3774428. https://doi.org/10.3390/ijerph10083121

Bajurna, B., Zdanowska, J., \& Mendyka, L. (2012). Sources of nurses' knowledge about mobbing. Polish Nursing /Pielegniarstwo Polskie, 43(1), 20-4. Retrieved from https://search-ebscohostcom.ezproxy.sastudents.uwi.tt/login.aspx?direct=true\&db=rzh\&AN=107953499\&site=ehost-live

Bartholomew, K. (2011). Break the spell and end lateral violence in nursing. Retrieved July, 2019, from http://www.nursetogether.com/Career/CareerArticle/itemId/2621/Break-the-Spell-and-End-Lateral-Violence -inNursin.aspx

Berry, P. A., Gillespie, G. L., Gates, D., \& Schafer, J. (2012). Novice Nurse Productivity Following Workplace Bullying. Journal of Nursing Scholarship, 44(1), 80-7. https://doi.org/10.1111/j.1547-5069.2011.01436.x

Chapovalov, O., \& Van Hulle, H. (2015). Workplace Bullying in Nursing -- Part 1: Prevention through Awareness. OOHNA Journal, 34(2), 20-4.

Chatziioannidis, I., Bascialla, F. G., Chatzivalsama, P., Vouzas, F., \& Mitsiakos, G. (2018). Prevalence, causes and mental health impact of workplace bullying in the Neonatal Intensive Care Unit environment. BMJ Open, 8(2), 1-9. https://doi.org/10.1136/bmjopen-2017-018766

Durmus, S. C., Topcu, I., \& Yildirim, A. (2018). Mobbing Behaviors Encountered by Nurses and their Effects on Nurses. International Journal of Caring Sciences, 11(2), 905-13. Retrieved from https://search-ebscohost-com.ezproxy.sastudents.uwi.tt/login.aspx?direct=true\&db=rzh\&AN=131851631\&s ite $=$ ehost-live

Essen, S. D., Esquival, C., \& Jha, P. (2014). Workplace bullying: An emergent issue. Oral Health and Dental Management, 13(3), 835-41.

Gaffney, D. A., Demarco, R. F., Hofmeyer, A., Vessey, J. A., \& Budin, W. C. (2012). Making Things Right: Nurses Experiences with Workplace Bullying-A Grounded Theory. Nursing Research and Practice, 1-10. https://doi.org/10.1155/2012/243210

Hansen, A. M., Hogh, A., Persson, R., Karlson, B., Garde, A. H., \& Ørbæk, P. (2006). Bullying at work, health outcomes, and physiological stress response. J. Psychosom. Res., 60, 63-72. https://doi.org/10.1016/j.jpsychores.2005.06.078

Harcombe, J. (1999). Power and political power positions in maternity care. British Journal of Midwifery, 7(2), 78-82. https://doi.org/10.12968/bjom.1999.7.2.8388

Houser, J. (2018). Nursing research: reading, using, and creating evidence. Burlington, MA: Jones \& Bartlett Learning.

ILO/ICN/WHO/PSI. (2003). Workplace violence in the health sector country case study research instruments. 
Survey questionnaire English, 2003[cited 2018Nov16]. Revied from https://www.who.int/violence_injury_prevention/violence/interpersonal/en/WVquestionnaire.pdf

Jackson, M., \& Ashley, D. (2005). Physical and psychological violence in Jamaica's health sector. Revista Panamericana de Salud Pública, 18(2), 114-21. https://doi.org/10.1590/S1020-49892005000700006

Johnson, S., Boutain, D., Tsai, J., \& de Castro, A. B. (2019). Managerial and Organizational Discourses of Workplace Bullying. J Nurs Adm, 45(9), 457-61. Retrieved from https://www.ncbi.nlm.nih.gov/pmc/articles/PMC5570583/

Johnston, M., Phanhtharath, P., \& Jackson, B. S. (2009). The Bullying Aspect of Workplace Violence in Nursing. Critical Care Nursing Quarterly, 32(4), 287-95. https://doi.org/10.1097/CNQ.0b013e3181bad5ef

Kang, J., \& Lee, M. (2016). The Related Factors to Workplace Bullying in Nursing: A Systematic Review and Meta-analysis. Korean Journal of Adult Nursing, 28(4), 399-414. https://doi.org/10.7475/kjan.2016.28.4.399

Khubchandani, J., \& Price, J. H. (2015). Workplace Harassment and Morbidity Among US Adults: Results from the National Health Interview Survey. J. Community Health, 40, 555-563. https://doi.org/10.1007/s10900-014-9971-2

Leos-Sheridan. N. (2008). Professional issues. Understanding lateral violence in nursing. Clinical Journal of Oncology Nursing, 12(3), 399-403. PMid:18515237. https://doi.org/10.1188/08.CJON.399-403

Lipscomb, J., London, M., McPhaul, K. M., Ghaziri MEl Lydecker, A., Geiger-Brown, J., \& Johnson, J. V. (2012). The Prevalence of Coworker Conflict Including Bullying in a Unionized U.S. Public Sector Workforce. Violence Vict., 30, 813-829. https://doi.org/10.1891/0886-6708.VV-D-14-00031

Lowenstein, L. F. (2013). Bullying in nursing and ways of dealing with it. Nursing Time, 109(11), 22-5.

McGee, J. L. (2014). Managing workplace bullying: A baseline assessment of nurses' knowledge. Retrieved from https://search-ebscohost-com.ezproxy.sastudents.uwi.tt/login.aspx?direct=true\&db=rzh\&AN=123296050\&s ite $=$ ehost-live

McMahon, J., MacCurtain, S., O'Sullivan, M., Murphy, C., \& Turner, T. (2013). A Report on the Extent of Bullying and Negative Workplace Behaviors Affecting Irish Nurses. Retrieved from https://inmo.ie/tempDocs/University of Limerick Report April 2015.pdf

Meires, J. (2018). Workplace Incivility - The Essentials: Here's What You Need to Know about Bullying in Nursing. Urologic Nursing, 38(2), 95-8. https://doi.org/10.7257/1053-816X.2018.38.2.95

Nelson, S. A., Azevedo, P. R., Dias, R. S., Sousa, S. M. A. D., Carvalho, L. D. P. D., Silva, A. C. O., et al. (2014). The influence of bullying on the wellbeing of Brazilian nursing professionals. Public Money \& Management, 34(6), 397-404. https://doi.org/10.1080/09540962.2014.962364

Norton, P., Costa, V., Teixeira, J., Azevedo, A., Roma-Torres, A., Amaro, J., \& Cunha, L. (2017). Prevalence and Determinants of Bullying Among Health Care Workers in Portugal. Workplace Health Saf., 65, 188-196. https://doi.org/10.1177/2165079916666545

Oxenstierna, G., Elofsson, S., Gjerde, M., Magnusson Hanson, L., \& Theorell, T. (2012). Workplace bullying, working environment and health. Ind. Health, 50, 180-188. https://doi.org/10.2486/indhealth.MS1300

Purpora, C., Cooper, A., \& Sharifi, C. (2015). JBI Database of Systematic Reviews and Implementation Reports. Retrieved from https://www.nursingcenter.com/journalarticle?Article_ID=3470302\&Journal_ID= 3425880\&Issue_ID $=3470019 \#$ P 82

Quine, L. (2001). Workplace Bullying in Nurses. Journal of Health Psychology, 6(1), 73-84. https://doi.org/10.1177/135910530100600106

Simons, S. R., \& Mawn, B. (2010). Bullying in the Workplace-A Qualitative Study of Newly Licensed Registered Nurses. AAOHN Journal, 58(7), 305-11. https://doi.org/10.1177/216507991005800705

Tinaz, P. (2006). Psychological harassment at workplace (mobbing). Journal of Work and Society, 13-28.

Wilson, J. L. (2016). An exploration of bullying behaviors in nursing: a review of the literature. British Journal of Nursing, 25(6), 303-6. PMid:27019166. https://doi.org/10.12968/bjon.2016.25.6.303

$\begin{array}{llll}\text { Workplacebullying.org. } & \text { Retrieved } & \text { November, } & \text { 2018, }\end{array}$ https://www.workplacebullying.org/individuals/problem/definition/

Zhao, L., Tian, L., Cai, T., Claggett, B., \& Wei, L. J. (2013). Effectively Selecting a Target Population for a Future 
Comparative Study. Journal of the American Statistical Association, 108(502), 527. PMid:24058223; PMCid:PMC3775385. https://doi.org/10.1080/01621459.2013.770705

\section{Copyrights}

Copyright for this article is retained by the author(s), with first publication rights granted to the journal.

This is an open-access article distributed under the terms and conditions of the Creative Commons Attribution license (http://creativecommons.org/licenses/by/4.0/). 